Chapman University

Chapman University Digital Commons

Pharmacy Faculty Articles and Research

School of Pharmacy

$11-14-2018$

\title{
Beyond Continuing Education: Continuing Professional Development and the CTH
}

Jeff Goad

Chapman University,goad@chapman.edu

Follow this and additional works at: https://digitalcommons.chapman.edu/pharmacy_articles

Part of the Health and Medical Administration Commons, Interprofessional Education Commons, and the Other Medicine and Health Sciences Commons

\section{Recommended Citation}

Goad J. Beyond continuing education: continuing professional development and the CTH. J Travel Med. 2018;26(3):tay128. https://doi.org/10.1093/jtm/tay128

This Letter to the Editor is brought to you for free and open access by the School of Pharmacy at Chapman University Digital Commons. It has been accepted for inclusion in Pharmacy Faculty Articles and Research by an authorized administrator of Chapman University Digital Commons. For more information, please contact laughtin@chapman.edu. 


\section{Beyond Continuing Education: Continuing Professional Development and the $\mathrm{CTH}$}

\section{Comments}

This is a pre-copy-editing, author-produced PDF of a letter accepted for publication in Journal of Travel Medicine, volume 26, issue 3, in 2018. The definitive publisher-authenticated version is available online at DOI: $10.1093 / \mathrm{jtm} /$ tay 128.

\section{Copyright}

International Society of Travel Medicine 


\title{
Beyond Continuing Education: Continuing Professional Development and the CTH
}

\author{
Jeff Goad, Pharm.D., MPH, FISTM \\ Chair, Continuing Professional Development Committee
}

In September 1999, the International Society of Travel Medicine (ISTM) began the process of creating the Body of Knowledge for the practice of travel medicine. This blueprint for the educational needs of a practicing travel medicine provider has been revised three times since its original release (2006, 2012, and 2017) and is available online (http://www.istm.org/bodyofknowledge2). This outline provides the main content areas and relative weighting of topics that are mapped to the ISTM Certificate of Knowledge exam. The exam was first given in 2003 in New York City and has subsequently been administered globally at least once a year in conjunction with the Congress of the ISTM (CISM) or a regional travel medicine meeting. Successfully completing the exam confers the Certificate in Travel Health (CTH) credential. As of January 2018, the exam had been given 16 times with now more than 2,500 CTH exam holders representing 67 countries. ${ }^{1}$ The $\mathrm{CTH}$ exam is taken by physicians, pharmacists and nurses. From country to country and profession to profession, there is a wide variety in the travel clinic practice and the training of travel medicine providers. One time assessments, such as the CTH exam, is important to establishing a standard level of knowledge, but ongoing education that focuses on the knowledge and skills necessary to provide the pre-travel clinic consultation should be a priority. ${ }^{2} \mathrm{~A}$ recent bibliometric mapping of the Journal of Travel Medicine with the ISTM Body of Knowledge revealed that published articles since 1994 have covered the major areas of emphasis, especially pretravel/consultation (30.5\% of all published articles). ${ }^{3}$

In 2011, the ISTM Certificate in Travel Health Renewal Program (CTHRP) was initiated to help ensure that the holders of the $\mathrm{CTH}$ remain current and engaged in the field of travel medicine. The CTHRP requires $\mathrm{CTH}$ holders to renew their certificate every 10 years either through Continuing Professional Development (CPD) or re-taking the CTH exam. The CTHRP CPD pathway allocates points to specific areas important for maintaining competence in travel medicine including attending and providing continuing education, clinical practice, scholarship, professional travel medicine association work and other related travel medicine work. At least $70 \%$ of the CPD pathway is allocated to continuing education. Over the last 20 years, the availability of travel medicine continuing education and training program have improved, but are still discontinuous across medicine, pharmacy and nursing. ${ }^{4}$ The ISTM chose CPD instead of just requiring CE as the former offers the opportunity for travel medicine providers to embrace a lifelong approach to enhancing their knowledge and skills.

The World Health Organization defines CPD as "The wide-ranging competencies beyond clinical update, research and scientific writing, multidisciplinary context of patient care, ethical practice, communication, management and behavioral skills, team building, information technology, audit, and appropriate attitudinal change to ensure improved patient outcomes and satisfaction." 5 The ISTM believes this comprehensive approach to lifelong learning will result in the public and healthcare providers having greater confidence in the travel medicine knowledge and skills of the CTH holder. 
1. Landry P. The certificate in travel health. J Travel Med. 2018;25(1).

2. Cegolon L, Heymann WC, Lange JH, Xodo C. Travel health education. J Travel Med. 2017;24(5).

3. Flaherty GT, Lim Yap K. Bibliometric analysis and curriculum mapping of travel medicine research. J Travel Med. 2017;24(5).

4. Kozarsky PE, Steffen R. Travel medicine education-what are the needs? J Travel Med. 2016;23(5).

5. WHO. Regional Guidelines for Continuing Medical Education (CME)/Continuing Professional Development (CPD) Activities. 2010. Available at http://apps.who.int/iris/handle/10665/205767 <last accessed November 5, 2018> 